\title{
Molecular Analysis of Argininosuccinate Synthetase Deficiency in Human Fibroblasts
}

\author{
Tsung-Sheng Su, Hans-Georg O. Bock, Arthur L. Beaudet, \\ and William E. O'Brien, Departments of Pediatrics and Cell \\ Biology, Baylor College of Medicine, Houston, Texas 77030
}

\begin{abstract}
A в S T R A C T We have analyzed cultured skin fibroblasts derived from patients with argininosuccinate synthetase deficiency for alterations in gene structure, mRNA content, and protein structure. Genomic DNA was digested with the endonucleases EcoRI or HindIII, and the fragments were analyzed by Southern blotting and hybridization with a cDNA probe for argininosuccinate synthetase. The blot pattern is complex because there are at least 10 copies of argininosuccinate synthetase-like genes scattered over multiple human chromosomes. All nine patients studied showed patterns of DNA fragments that were indistinguishable from the normal control cell lines, and despite the possibility that the complexity could mask some changes, major deletions of the active gene(s) were not present. Blot hybridization of RNA indicated the presence of hybridizable mRNA of approximately normal size in seven of seven individuals examined with a suggestion of some heterogeneity. Analysis of enzyme antigen by protein transfer from $\mathrm{NaDodSO}_{4}$ containing polyacrylamide gels revealed considerable heterogeneity. This analysis revealed no cross-reacting material (CRM) in nine cell lines, CRM of normal molecular weight in one cell line, and CRM of reduced molecular weight in one cell line. These findings suggest that the genes for argininosuccinate synthetase in most citrullinemia patients are transcribed and produce stable mRNA. These mRNA either are not translated, or the translation product (enzyme) is rapidly degraded or is immunologically nonreactive. Defective gene expression in this disorder appears to involve abnormal mRNA, which may be altered by point mutations, frame shift mutations, deletions, insertions or particularly by abnormal RNA processing.
\end{abstract}

This work was presented in part in abstract form at the Annual Meeting of the American Society of Human Genetics, Dallas, TX. (1981. Am. J. Hum. Genet. 33: 36a.).

\section{INTRODUCTION}

Citrullinemia is an inborn error of metabolism resulting from the deficiency of argininosuccinate synthetase (E.C. 6.3.4.5) (see reference 1 for review). The enzyme is present in all tissues, but the level of enzyme activity is highest in the liver where the enzyme functions in the urea cycle for elimination of ammonia. Patients exhibit profound elevations of ammonia and citrulline in the blood. There is clinical heterogeneity within the reported cases. The majority of Caucasian patients have severe disease and present in the neonatal period with hyperammonemic coma. This form of disease usually was rapidly fatal prior to the recent development of improved dietary therapy (2). There are cases in which a later presentation with less clinical difficulty is associated with partial enzyme deficiency, and these patients are particularly frequent in the Japanese population $(3,4)$. Tedesco and Mellman (5) and Kennaway et al. (6) reported changes in the Michaelis constant $\left(K_{m}\right)$ values for citrulline and aspartate for the enzyme from two different patients suggesting further genetic heterogeneity within the neonatal citrullinemia group.

The availability of a specific antibody (7) and cloned cDNA probe (8) offers the opportunity for more detailed analysis of the citrullinemia mutation at the protein and nucleic acid levels. The DNA and mRNA analyses that have been carried out for the human hemoglobin abnormalities are now possible for this inborn error of metabolism. It is known that there are multiple argininosuccinate synthetase-like genes in the human genome (8), and these genes occur on at least 10 different human chromosomes (9). Since citrullinemia is a single gene recessive disorder, the multiple argininosuccinate synthetase-like genes may represent one or a few expressed genes and multiple pseudogenes. We report here the results of analysis of the enzyme antigen, messenger RNA, and genomic DNA 
for argininosuccinate synthetase in cultured cell lines derived from patients with citrullinemia. The data indicate the presence of stable, altered mRNA in most citrullinemia patients.

\section{METHODS}

Cell lines. Fibroblast cell lines designated GM1679, GM63, GM1684, GM1044, and GM3056 and lymphoblast line GM235 were obtained from the Human Genetic Mutant Cell Repository (Camden, NJ). Fibroblast lines 933, 1173, and 1263 were from Roderick McInnes (Hospital for Sick Children, Toronto, Canada); lines BS and family members from Louis Elsas and Dean Danner (Emory University School of Medicine, Atlanta, GA); and line MV from Douglas Kerr (Case Western Reserve University Cleveland, $\mathrm{OH}$ ). Fibroblast lines AC and CG were established in our laboratory. Except where indicated, patients are unrelated. After completion of these studies, we became suspicious that cell lines GM1679 and GM3056 might be related. We have now confirmed that, unknown to the Human Genetic Mutant Cell Repository, these two lines were taken from the same patient at $1 \mathrm{~d}$ and $3 \mathrm{yr}$ of age, respectively. Patient C.G. is the product of a first-cousin mating, and patient $\mathrm{AC}$ has one Caucasian parent and one Japanese parent. Cells were cultured in Dulbecco's modified Eagle medium with $10 \%$ fetal calf serum.

Enzyme assay, antigen analysis, and incorporation of $\left[{ }^{14} \mathrm{C}\right]$ citrulline into intact cells. Argininosuccinate synthetase was assayed as described previously (10). Antibodies to human liver argininosuccinate synthetase were prepared as described (7), and protein transfer to diazobenzyloxymethyl $(\mathrm{DBM})^{1}$ paper was conducted according to Symington et al. (11). For incorporation of radioactive amino acids, cultured skin fibroblasts were seeded with $5 \times 10^{5}$ cells $/ 60-\mathrm{ml}$ plate. After $48 \mathrm{~h}$ of growth, the medium was removed, and the cells were rinsed twice with Earle's balanced salt solution followed by addition of $1 \mathrm{ml}$ of radioactive medium. The radioactive medium was composed of serum-free minimal Eagle's medium without arginine and leucine. $1 \mathrm{ml}$ of medium contained $0.5 \mu \mathrm{Ci}$ of $\left[{ }^{14} \mathrm{C}\right]$ citrulline (sp act $54 \mathrm{mCi} /$ $\mathrm{mmol}$ ) and $10 \mu \mathrm{Ci}$ of $\left[{ }^{3} \mathrm{H}\right]$ leucine (sp act $51 \mathrm{Ci} / \mathrm{mmol}$ ). At the indicated times, duplicate plates were harvested and radioactivity was determined as described previously (12).

RNA and DNA analyses. DNA was isolated from cultured cells as described by Wigler et al. (13) and total RNA was prepared as described by Wahl et al. (14). Nucleic acids were separated on agarose gels by electrophoresis and transferred to nitrocellulose filters for DNA analysis, or to DBM paper for RNA analysis using standard methods (8). DNA fragments and RNA molecules were detected by hybridization to the ${ }^{32} \mathrm{P}$-labeled $1.5 \mathrm{~kb}$ insert from pASl, the plasmid containing the cDNA for argininosuccinate synthetase (8). Unpublished sequence data indicate that this clone contains only seven bases of the poly(A) tract. Restriction endonucleases were used as recommended by the supplier (New England BioLabs, Boston, MA, or Bethesda Research Laboratories, Rockville, MD).

\section{RESULTS}

Enzyme activity. The range of enzyme activity in extracts of normal human cultured fibroblasts was 1.0-

\footnotetext{
${ }^{1}$ Abbreviations used in this paper: CRM, cross-reacting
} material; DBM, diazobenzyloxymethyl.
$4.0 \mathrm{nmol} / \mathrm{min}$ per $\mathrm{mg}$ of protein. The method of assay measures the conversion of $\left[{ }^{14} \mathrm{C}\right]$ asparate to $\left[{ }^{14} \mathrm{C}\right]-$ argininosuccinate. Under the conditions of assay, all citrullinemia cell lines included in these studies had an activity of $<0.02 \mathrm{nmol} / \mathrm{min}$ per $\mathrm{mg}$ of protein. This was true for cell line GM63, which was reported by others to be a kinetic mutant using different methods of enzyme assay (5). Analysis of both parents and a sibling (M.S.) of patient B.S. indicated that all three individuals had enzyme activities ranging from 0.1 to $0.3 \mathrm{nmol} / \mathrm{min}$ per $\mathrm{mg}$, i.e. only 5 to $10 \%$ of normal.

In vivo incorporation of $\left[{ }^{14} \mathrm{C}\right]$ citrulline into protein. The incorporation of $\left[{ }^{14} \mathrm{C}\right]$ citrulline into protein was measured with simultaneous determination of the incorporation of $\left[{ }^{3} \mathrm{H}\right]$ leucine for purposes of constructing a ratio (Table $\mathrm{I}$ ). The absolute incorporation was approximately linear over $4 \mathrm{~h}$, and the ratio of $\left[{ }^{14} \mathrm{C}\right] \mathrm{cit}$ rulline incorporation to $\left[{ }^{3} \mathrm{H}\right]$ leucine incorporation remained within a narrow range for control fibroblasts. The incorporation by the fibroblasts of two heterozygotes was close to the normal range despite a level of enzyme activity in the range of 5 to $10 \%$ of normal.

TABLE I

Incorporation of $\left[{ }^{14} \mathrm{C}\right]$ Citrulline into Protein by Cultured Fibroblasts ${ }^{\circ}$

\begin{tabular}{cccc}
\hline Cell line & $\begin{array}{c}\left.{ }^{14} \mathrm{C}\right] \text { Citrulline incorporation } \\
\mathrm{CPM} \times 10^{-3}\end{array}$ & $\begin{array}{c}\text { Ratio: } \\
\text { citrulline/leucine }\end{array}$ \\
\hline $2 h$ & $4 h$ & $2 h$ & $4 h$
\end{tabular}

Control

$\begin{array}{lrcrr}\text { T.K. } & 4.4,2.3 & 11.1,5.3 & 85,57 & 99,70 \\ \text { C.C. } & 5.8,4.4 & 13.9,13.8 & 95,63 & 120,90 \\ \text { M.N. } & 4.6,3.7 & 9.6,9.1 & 79,48 & 88,77\end{array}$

Heterozygote

M.S., sib of B.S.

$$
4.6
$$

9.6

81

81

J.S., mother of B.S.

5.0

10.3

86

100

Citrullinemia

\begin{tabular}{lrrrr} 
GM63 & 0.07 & 0.13 & 1.3 & 1.3 \\
GM1044 & $<0.01$ & 0.01 & 0.1 & 0.2 \\
GM1679 & 0.03 & 0.06 & 0.5 & 1.1 \\
GM3056 & 0.05 & 0.13 & 0.8 & 1.5 \\
B.S. & 0.01 & 0.02 & 0.2 & 0.1 \\
A.C. & $<0.01$ & $<0.01$ & $<0.1$ & $<0.1$ \\
M.V. & 0.02 & 0.03 & 0.2 & 0.2 \\
\hline
\end{tabular}

- All values are the average of duplicate plates. Two sets of numbers indicate repeat experiments at different times on the same cell lines. The ratios in columns three and four were constructed by dividing the $\left[{ }^{14} \mathrm{C}\right]$ citrulline incorporation by the $\left[{ }^{3} \mathrm{H}\right]$ leucine incorporation and multiplying by 1,000 .

$\ddagger$ Different cell lines from the same patient. 
All citrullinemia cell lines showed almost no incorporation of $\left[{ }^{14} \mathrm{C}\right]$ citrulline. The differences among the deficient cell lines may be significant. For example, line GM1044 yielded a ratio only 0.1 to $0.2 \%$ of the control ratio, whereas cell line GM63, a reported kinetic mutant, yielded a ratio of 1 to $2 \%$ of the control value.

Blot hybridization of cellular DNA. Genomic DNA was prepared from cultured fibroblasts and was analyzed by digestion with restriction endonucleases and blot hybridization. For interpretation of this analysis, it is important to know that there are multiple copies of argininosuccinate synthetase-like genes in human DNA (8) and that the genes map to at least 10 different human chromosomes (9), including chromosome $9, X$, and 6 . Expression of argininosuccinate synthetase activity has been mapped to human chromosomes 9 (15), and although we have considered this assignment open to some question (9), we believe that it is correct. We have assigned the largest $31-\mathrm{kb}$ fragment in the EcoRI blot pattern and also the $3.9 \mathrm{~kb}$ and $2.7 \mathrm{~kb}$ fragments in the HindIII digest to chromosome 9. The results of this analysis for multiple citrullinemia cell lines using the restriction enzymes EcoRI and HindIII are shown in Figs. 1 and 2, respectively. Results for cell lines CG, MV, and GM235 are not shown, but were similar. In

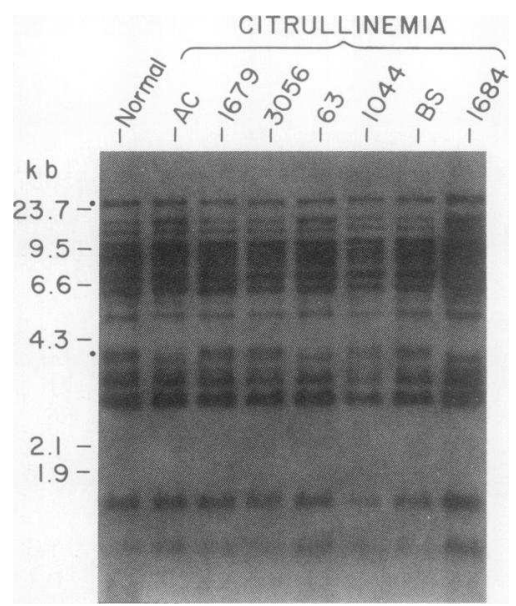

FIGURE 1 Autoradiograph of a blot hybridization of EcoRI cleaved DNA from citrullinemia and normal fibroblasts. Genomic DNA $(5 \mu \mathrm{g})$ from one control and seven citrullinemia cell lines was digested with restriction endonuclease, $E c o R I$, and electrophoresed in $0.8 \%$ agarose. The DNA was transferred to nitrocellulose paper and hybridized for $40 \mathrm{~h}$ at $66^{\circ} \mathrm{C}$ with nick-translated $\left.{ }^{32} \mathrm{P}\right] \mathrm{cDNA}\left(4 \times 10^{6} \mathrm{cpm}, 1.5\right.$ $\times 10^{8} \mathrm{cpm} / \mu \mathrm{g}$ ) prepared from the $1.55-\mathrm{kb}$ insert of pASl. Dots at the left margin indicate $31-$ and $4.2-\mathrm{kb}$ bands discussed in the text. Note that, as explained in Methods and relevant to Figs. 1 to 4, cell lines GM1679 and GM3056 are from the same patient.

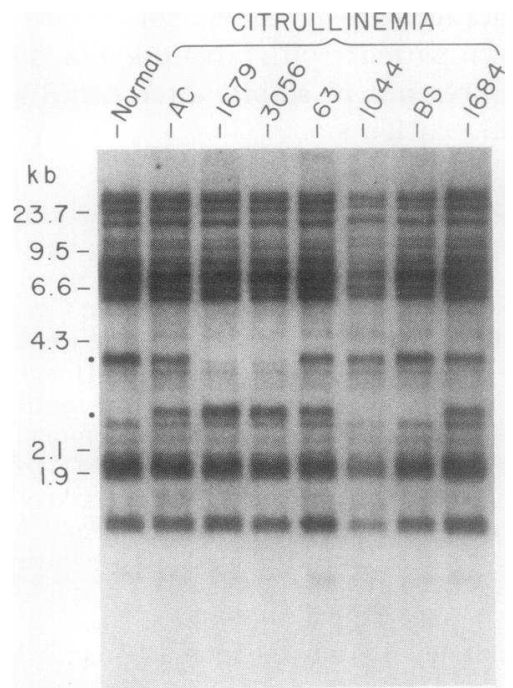

FIGURE 2 Autoradiograph of a blot hybridization of HindIII cleaved DNA from citrullinemia and normal fibroblasts. Conditions were as described for Fig. 1. Dots at the left margin indicate $3.9-$ and $2.7-\mathrm{kb}$ bands discussed in the text.

all cases, the pattern of fragments observed was similar to that observed in normal individuals. Certain differences were observed. A $4.2-\mathrm{kb}$ fragment in the EcoRI analysis was present in lines GM1679, GM3056, GM1044, and BS, but was absent in lines AC, GM63, and GM1684. This fragment was observed in all male individuals and was absent in all female individuals (16). Another difference was the occurrence of a restriction fragment length polymorphism in the HindIII analysis in Fig. 2. There were two allelic fragments at 2.7 and $3.9 \mathrm{~kb}$. The normal cell line is $3.9^{+} / 2.7^{-}$; $\mathrm{AC}$ was $3.9^{+} / 2.7^{+}$; and $\mathrm{GM} 1679$ was $3.9^{-} / 2.7^{+}$. All forms of this polymorphism have been observed in normal individuals. These results suggest that large deletions of the structural gene are not the basis of the disease in these patients. The possibility of some differences in the pattern of DNA fragments cannot be entirely eliminated because of the complexity of the blotting analysis.

Blot hybridization of cellular mRNA. Total RNA was isolated from cultured fibroblasts, denatured with glyoxal, and fractionated by electrophoresis in agarose gels. RNA was transferred to DBM paper and detected by hybridization with $\left.{ }^{32} \mathrm{P}\right] \mathrm{DNA}$ probe. In five disease cell lines (lines GM1679 and GM3056 are the same patient) shown in Fig. 3 and in cell lines CG, BS, and GM235 (not shown), there was a radioactive band that indicated the presence of hybridizable mRNA for argininosuccinate synthetase. In all cases the mRNA migrated with a retardation factor $\left(R_{f}\right)$ similar (see 


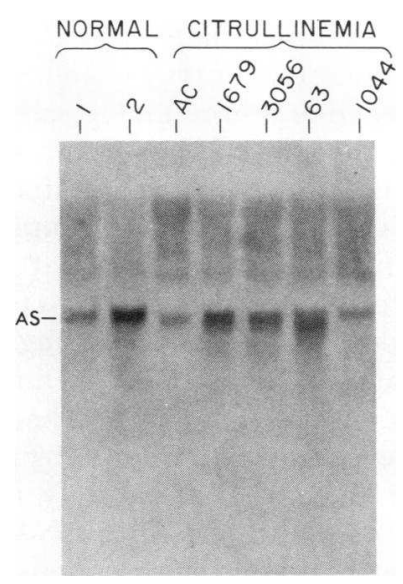

FIGURE 3 Autoradiograph of a blot hybridization of total RNA from citrullinemia and normal fibroblasts. Total RNA $(20 \mu \mathrm{g})$ from two control and five citrullinemia cell lines was denatured with glyoxal and applied to a 1\% agarose gel for electrophoresis. The RNA was transferred to DBM paper and hybridized with nick-translated $\left[{ }^{32} \mathrm{P}\right] \mathrm{cDNA}\left(1.5 \times 10^{8} \mathrm{cpm} /\right.$ $\mu \mathrm{g}, 1.4 \times 10^{7} \mathrm{cpm}$ total) for $45 \mathrm{~h}$ at $42^{\circ} \mathrm{C}$.

below for minor differences) to the control cells and was $\sim 1,700$ bases in length, which agrees with the previously determined size of the argininosuccinate synthetase mRNA (8). Since equal amounts of total cellular RNA rather than poly $(\mathrm{A})^{+} \mathrm{RNA}$ were applied for analysis in Fig. 3, the relative intensity of bands should not be interpreted quantitatively. The detection of hybridizable mRNA supports the interpretation that large structural gene deletions have not occurred in these patients.

Slight differences in the migration of some RNA are visible in Fig. 3 . The bands may migrate more rapidly or be broader with a faster moving component for AC, GM1679, GM3056, and GM63. In contrast, GM1044 appears indistinguishable from the normal. Although we are reluctant to overinterpret these data, preliminary S1 nuclease mapping studies suggest the differences are significant. The presence of somewhat greater relative intensity of radioactivity with the faint suggestion of bands in the region above the mature RNA (compare control 2 and AC in Fig. 3) could be compatible with defects in mRNA processing with excessive accumulation of processing intermediates. In other experiments, a larger minor RNA specie similar to that observed previously (8) was visible in some RNA preparations from control and disease cell lines. The nature and significance of the minor RNA component is unknown at this time, and it is at the limits of detection with RNA from cultured fibroblasts.

Immunological analysis of argininosuccinate synthetase. The presence of immunologically cross-re- acting material (CRM) in cell extracts was determined after electrophoresis in $\mathrm{NaDodSO}_{4}$ containing gels and transfer to DBM paper (Fig. 4). CRM was readily detected in all control lines but was not detectable in 9 of 11 citrullinemia cell lines examined. Only two citrullinemia cell lines (Fig. 5) gave clear evidence of the presence of an immunologically detectable protein. In cell line $M V$, multiple experiments revealed that the cross-reacting protein was smaller than the normal gene product, but the CRM was present in normal quantity. Cell line 1173 had less cross-reacting protein than the normal, but the product was of the same molecular weight. We were able to detect 5-10\% of the normal amount of cross-reacting protein found in control fibroblasts with this analysis. One heterozygote, M.S., is shown in Fig. 4 and only a very small amount of CRM was evident. The parents of M.S. and B.S. also showed very small amounts of CRM that correlated with the low levels of enzyme activity in these cell lines. Although this study is not quantitative, it is clear that the amount of CRM present in these heterozygotes was considerably less than $50 \%$ and may be as little as $5 \%$.

\section{DISCUSSION}

Analysis of citrullinemia cell lines at the DNA level using restriction endonuclease techniques did not re-

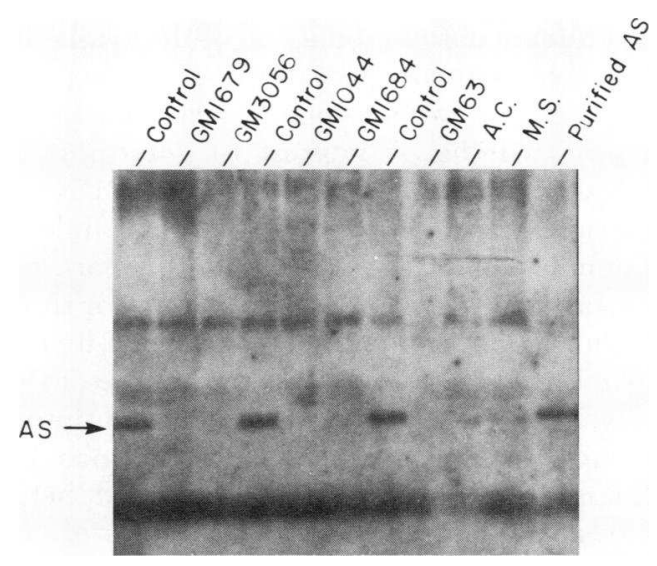

Figure 4 Autoradiograph of a protein transfer blot of extracts from citrullinemia and normal fibroblasts. Each lane contains $200 \mu \mathrm{g}$ of protein as crude cell extract. Cell line MS is a heterozygote, and other cell lines are affected with citrullinemia. $100 \mathrm{ng}$ of purified argininosuccinate synthetase (AS) from liver was applied. The migration of the enzyme antigen is indicated by the arrow marked AS. Radioactive bands above and below the enzyme are thought to represent immunoglobulin reacting with ${ }^{125}$ I-protein A. Each $13 \times 13$ cm DBM paper was exposed to $2 \times 10^{6} \mathrm{cpm}$ of ${ }^{125} \mathrm{I}$-protein A. Autoradiography was for $18 \mathrm{~h}$. 


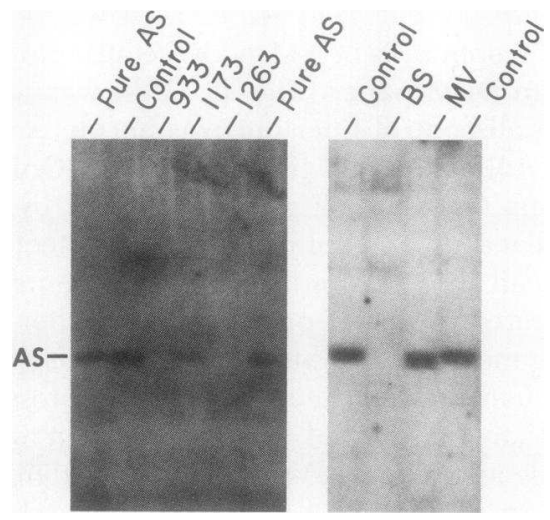

Figure 5 Autoradiograph of a protein transfer blot of extracts from citrullinemia and normal fibroblasts. $50 \mu \mathrm{g}$ of extract protein or $100 \mathrm{ng}$ of purified argininosuccinate synthetase was applied for each lane. Detection was as described in Fig. 4.

veal any detectable alterations. This analysis indicated that deletion of the entire gene was not the cause of enzyme deficiency in the cell lines examined. The complexity of the blot hybridization pattern could mask some changes, but analysis with two restriction enzymes did not reveal any significant changes other than variations also observed in normal individuals. Although the multiple copies of the argininosuccinate synthetase-like genes are distributed on at least 10 different human chromosomes, all of the available data are consistent with the hypothesis of a single active gene (located on chromosome 9) and multiple pseudogenes. It will be of interest to determine if the HindIII polymorphism, which involves DNA fragments assigned to chromosome 9 , is tightly linked with citrullinemia phenotype, and if patients born of consanguineous matings will be homozygous for this polymorphism. Patient C.G. is the product of a first cousin mating and is homozygous for the presence of the 3.9$\mathrm{kb}$ fragment. Throughout these analyses it is important to remember that there is a substantial chance that the citrullinemia patients may be compound heterozygotes, except where patients are products of consanguineous matings.

The analysis of mRNA for the mutant cell lines was consistent with the hypothesis that no major deletion in the structural gene has occurred in these individuals. Hybridizable mRNA was detected in all cell lines studied and was of near normal size in all instances. The presence of mRNA in cultured fibroblasts from these patients will facilitate the determination of the exact molecular defect. The findings indicate that the genes for argininosuccinate synthetase are transcribed and produce stable mRNA in these patients. These mRNA either are not translated, or they encode a product that is rapidly degraded or is immunologically nonreactive. Taking into account the subtle differences in the RNA blotting analysis discussed above, preliminary analysis of mRNA by S1 nuclease mapping (unpublished data) and ongoing studies that indicate that the expressed gene is very large with multiple introns (17); we would speculate that defects in RNA processing and base substitutions in mature normally processed mRNA will be the two most common categories. The frequency of processing defects may be somewhat proportional to the number of introns, both possibly being high in citrullinemia. Base substitutions in DNA can result in altered processing with net insertions and/or deletions in the improperly spliced RNA. Abnormal processing of RNA is now documented in detail for many thalassemia mutations (18-20). Deletions, insertions, and frameshift mutations at a DNA level are also possible explanations for the findings reported here.

The results obtained from the immunological studies provided clear evidence of heterogeneity within the citrullinemia cell lines. Only 2 of the 11 cell lines tested showed any evidence of CRM. Interestingly, one of these cell lines (1173) has been shown to be a kinetic mutant by Kennaway et al. (6). Cell line GM63, which has also been reported to be a kinetic mutant $(5,6)$, does not show any evidence of cross-reactive protein. This apparent discrepancy may be due to the presence of a very labile protein in this cell line or a mutation that has altered the primary recognition site for the antibody being used. Patient M.V. presents a different mutation. The quantity of cross-reacting protein appears normal and is $\sim 2,000-3,000$ daltons smaller than the normal argininosuccinate synthetase monomer. We have no data on the parents of this patient.

Of the possible explanations for the absence of crossreacting immune material in the presence of mRNA, rapid degradation is an attractive possibility, since it might explain the unusually low argininosuccinate synthetase levels in some heterozygotes studied here and reported previously (21). Because human argininosuccinate synthetase is a tetramer (7), the association of a mutant subunit with normal subunits might result in an unstable tetramer with a short half-life. This would also explain the very low level of CRM observed in our heterozygous cell lines. Such interactions can occur even if the original mutant produces no detectable CRM, and the effect on wild type subunits presumably indicates that the mutant is capable of producing subunits despite the failure to detect antigen. For $\mathrm{CRM}^{+}$citrullinemia patients, it is possible that enzyme composed of mixed tetramers would not be degraded, and heterozygotes could have high or low 
levels of enzyme activity based on the catalytic properties of the mixed tetramers. Observations of this type are well documented for the dimeric alkaline phosphatase from Escherichia coli (22) and for the octameric glutamate dehydrogenase from Neurospora crassa (23). Significantly less than $50 \%$ of normal levels of activity have been reported for heterozygotes for a number of human recessive disorders including orotic aciduria (24), cystathionine synthase deficiency (25), and adenine phosphoribosyl transferase deficiency (26).

\section{ACKNOWLEDGMENTS}

We thank Diane Dicks, Anna Englund, and Mark Adcock for technical assistance; and Lynn Loewenstein for preparation of the manuscript.

This work was supported by fellowships for Dr. Su (GM08199) and for Dr. Bock (GM07466) and by research grants GM27593 and AM25938, all from the National Institutes of Health. Access to patients was enhanced by the support of General Clinical Research Center grant RR00188.

\section{REFERENCES}

1. Shih, V. E. 1978. Urea cycle disorders and other congenital hyperammonemic syndromes. In The Metabolic Basis of Inherited Disease. J. B. Stanbury, J. B. Wyngaarden, and D. S. Fredrickson, editors. McGraw-Hill Book Co., New York. 4th edition. 362-386.

2. Batshaw, M. L., G. H. Thomas, and S. W. Brusilow. 1981. New approaches to the diagnosis and treatment of inborn errors of urea synthesis. Pediatrics. 68: 290-297.

3. Matsuda, I., M. Anakura, S. Arashima, Y. Saito, and Y. Oka. 1976. A variant form of citrullinemia. J. Pediatr. 88: 824-826.

4. Saheki, T., A. Ueda, M. Hosoya, K. Kusumi, S. Takada, M. Tsuda, and T. Katsunuma. 1981. Qualitative and quantitative abnormalities of argininosuccinate synthetase in citrullinemia. Clin. Chim. Acta. 109: 325-335.

5. Tedesco, T. A., and W. J. Mellman. 1967. Argininosuccinate synthetase activity and citrulline metabolism in cells cultured from a citrullinemic subject. Proc. Natl. Acad. Sci. USA. 57: 829-834.

6. Kennaway, N. G., P. J. Harwood, D. A. Ramberg, R. D. Koler, and N. R. M. Buist. 1975. Citrullinemia: enzymatic evidence for genetic heterogeneity. Pediatr. Res. 9: 554-558.

7. O'Brien, W. E. 1979. Isolation and characterization of argininosuccinate synthetase from human liver. Biochemistry. 18: 5353-5356.

8. Su, T.-S., H.-G. O. Bock, W. E. O'Brien, and A. L. Beaudet. 1981. Cloning of cDNA for argininosuccinate synthetase mRNA and study of enzyme overproduction in a human cell line. J. Biol. Chem. 256: 11826-11831.

9. Beaudet, A. L., T.-S. Su, W. E. O'Brien, P. D'Eustachio, P. E. Barker, and F. H. Ruddle. 1982. Dispersion of argininosuccinate synthetase-like human genes to multiple autosomes and the $\mathrm{X}$ chromosome. Cell. 30: 287293.

10. Su, T.-S., A. L. Beaudet, and W. E. O'Brien. 1981. In- creased translatable messenger ribonucleic acid for argininosuccinate synthetase in canavanine-resistant human cells. Biochemistry. 20: 2956-2960.

11. Symington, J., M. Green, and K. Brackmann. 1981. Immunoautoradiographic detection of proteins after electrophoretic transfer from gels to diazo-paper: Analysis of adenovirus encoded proteins. Proc. Natl. Acad. Sci. USA. 78: 177-181.

12. Gillin, F. D., D. J. Roufa, A. L. Beaudet, and C. T. Caskey. 1972. 8-azaguanine resistance in mammalian cells. I. Hypoxanthine-guanine phosphoribosyltransferase. Genetics. 72: 239-252.

13. Wigler, M., R. Sweet, G. K. Sim, B. Wold, A. Pellicer, E. Lacy, T. Maniatis, S. Silverstein, and R. Axel. 1979. Transformation of mammalian cells with genes from procaryotes and eucaryotes. Cell. 16: 777-785.

14. Wahl, G. M., R. A. Padgett, and G. R. Stark. 1979. Gene amplification causes overproduction of the first three enzymes of UMP synthesis in $N$-(phosphonacetyl)-L-aspartate-resistant hamster cells. J. Biol. Chem. 254: 86798689.

15. Carritt, B., P. S. G. Goldfarb, M. L. Hooper, and C. Slack. 1977. Chromosome assignment of a human gene for argininosuccinate synthetase expression in Chinese hamster $\times$ human somatic cell hybrids. Exp. Cell Res. 106: 71-78.

16. Daiger, S. P., R. S. Wilden, and T.-S. Su. 1982. DNA sequences on the human $\mathrm{Y}$ chromosome homologous to argininosuccinate synthetase, an autosomal gene. Nature (Lond.). 298: 682-684.

17. Freytag, S. O., A. L. Beaudet, and W. E. O'Brien. 1982. Structure and molecular organization of the human argininosuccinate synthetase gene family. Am. J. Hum. Genet. 34: 160A.

18. Felber, B. K., S. H. Orkin, and D. H. Hamer. 1982. Abnormal RNA splicing causes one form of $\alpha$ thalassemia. Cell. 29: 895-902.

19. Treisman, R., N. J. Proudfoot, M. Shander, and T. Maniatis. 1982. A single-base change at a splice site in a $\beta^{0}$. thalassemic gene causes abnormal RNA splicing. Cell. 29: 903-911.

20. Ley, T. J., N. P. Anagnou, G. Pepe, and A. W. Nienhuis. 1982. RNA processing errors in patients with $\beta$-thalassemia. Proc. Natl. Acad. Sci. USA. 79: 4775-4779.

21. Christensen, E., N. J. Brandt, J. Philip, and N. G. Kennaway. 1980. Citrullinaemia: the possibility of prenatal diagnosis. J. Inher. Metab. Dis. 3: 73-75.

22. Garen, A., and S. Garen. 1963. Complementation in vivo between structural mutants of alkaline phosphatase from E. coli. J. Mol. Biol. 7: 13-22.

23. Sundaram, T. K., and J. R. S. Fincham. 1968. Nature of the complementation products formed by a complementing mutant of Neurospora crassa. J. Bacteriol. 95: 787-792

24. Fallon, H. J., L. H. Smith, J. B. Graham, and C. H. Burnett. 1964. A genetic study of hereditary orotic aciduria. N. Engl. J. Med. 270: 878-881.

25. Gaull, G., J. A. Sturman, and F. Schaffner. 1974. Homocystinuria due to cystathionine synthase deficiency: enzymatic and ultrastructural studies. J. Pediatr. 84: 381390.

26. Kelley, W. N., R. I. Levy, F. M. Rosenbloom, J. F. Henderson, and J. E. Seegmiller. 1968. Adenine phosphoribosyl deficiency: A previously undescribed genetic defect in man. J. Clin. Invest. 47: 2281-2289. 